\title{
The effect of air gap on the total and local thermal insulation of Chinese male costumes from twenty minority ethnic groups
}

\author{
Wen Shi, Hui Peng, Yehu Lu, Faming Wang ${ }^{*}$ \\ From 15th International Conference on Environmental Ergonomics (ICEE XV) \\ Portsmouth, UK. 28 June - 3 July 2015
}

\begin{abstract}
Introduction
Clothing thermal insulation is an important thermo-physical parameter to determine thermal comfort. Previous studies have shown that clothing thermal insulation can be largely affected by the air speed, the body movement, the body posture, clothing physical properties and design features [1,2]. Air gaps trapped within the clothing microenvironment is one of the inherent factors that determine the thermal insulation of the clothing [3]. In this study, the effect of air gap on the total and local thermal insulation of 20 sets of Chinese male costumes was investigated by a 3D body scanner and thermal manikin measurements.
\end{abstract}

\section{Methods}

A sample of twenty clothing ensembles of typical male ethnic costumes were selected from 20 Chinese minority groups. They were divided into 6 major groups based on their design characteristics. The total and local thermal insulation of those male costumes were measured on a 'Newton' thermal manikin, which was divided into 11 regions for data analysis. A constant surface temperature of $34.0^{\circ} \mathrm{C}$ was used. All tests were conducted in a climatic chamber, where the air velocity was $0.4(0.1) \mathrm{m} . \mathrm{s}^{-1}$. The test protocol strictly followed the ISO 15831 (2004) [4]. Three independent replications of tests for each ensemble were performed. The coefficient of variance of each test scenario should was within $10 \%$. To capture the 3D body shape and clothing air gap, a VITUS Smart 3D whole body laser scanner (Human Solutions GmbH, Kaiserslautern, Germany) was used. The nude manikin was first

\footnotetext{
* Correspondence: dr.famingwang@gmail.com Laboratory for Clothing Physiology and Ergonomics, the National Engineering Laboratory for Modern Silk, Soochow University, Suzhou,
} 215123, China
Local insulation results are highly correlated with the uneven distribution of the clothing local air gap. Based on the data of the air gap distribution, the total and local thermal insulation of each ethnic costume, a scatter chart with markers was plotted for those 20 male ethnic cosaccordingly. The total clothing thermal insulation prediction equation is $I_{t}=0.0002 V_{c l}{ }^{2}+0.022 V_{c l}+0.503\left(\mathrm{R}^{2}=0.55\right)$, and the total clothing area factor prediction equation is tumes and a linear regression equation was developed 
$f_{c l}=0.47^{*} I_{c l}+1.0\left(\mathrm{R}^{2}=0.54\right)$. The research findings contributed to the knowledge on clothing thermal comfort of Chinese male costumes, and hence provided a technical base for future thermal comfort studies.

Published: 14 September 2015

\section{References}

1. Lu Y, Wang F, Wan X, Song G, Zhang C, Shi W: Clothing resultant thermal insulation determined on a movable thermal manikin. Part II: effects of wind and body movement on local insulation. International Journal of Biometeorology 2015, DOI: 10.1007/s00484-015-0959-0.

2. Sung S: Study on the thermal insulation effect of Korean men's folk clothes. Journal of Thermal Biology 1993, 18(5/6):409-412.

3. Psikuta $A$, et al: Quantitative evaluation of air gap thickness and contact area between body and garment. Textile Research Journal 2012, 82(14):1405-1413.

4. ISO 15831: Clothing- Physiological Effects- Measurement of thermal insulation by means of a thermal manikin. Geneva: International Organization for Standardization; 2004.

doi:10.1186/2046-7648-4-S1-A89

Cite this article as: Shi et al:: The effect of air gap on the total and local thermal insulation of Chinese male costumes from twenty minority ethnic groups. Extreme Physiology \& Medicine 2015 4(Suppl 1):A89.

\section{Submit your next manuscript to BioMed Central} and take full advantage of:

- Convenient online submission

- Thorough peer review

- No space constraints or color figure charges

- Immediate publication on acceptance

- Inclusion in PubMed, CAS, Scopus and Google Scholar

- Research which is freely available for redistribution

Submit your manuscript at www.biomedcentral.com/submit 